\title{
Experience curves as a planning tool
}

\author{
Cedric Grant Robinson \\ School of Business Leadership, University of South Africa, Pretoria
}

In this article, the first of a series of two articles, the Boston Consulting Group's use of the experience curve as a strategic planning tool is explained. The experience effect is described and differences between learning curves, experience curves and economies of scale are highlighted. The effect of experience on product costs is described: costs don't just decline, they must be managed. The effects of experience on costs and prices are quantified, and sources of the experience effect amenable to strategic management are given. Strategic implications for competitive interaction using company experience are considered. (The second article, to be published, will explode some myths associated with the idyll. Perrhic victories in the quest for market share will be described and practical problems in applying the experience effect will be highlighted.)

S. Afr. J. Bus. Mgmt. 1982, 13: $101-112$

In dié artikel, die eerste in 'n reeks van twee, word die Boston Consulting Group se gebruik van die ervaringskurwe as 'n hulpmiddel in strategiese beplanning verduidelik. Die ervaringseffek word beskryf en die verskille tussen leerkurwes, ervaringskurwes en skaal-ekonomieè word beklemtoon. Die effek van ervaring op produkkoste word beskryf: koste daal nie sommer nie, hulle moet bestuur word. Die invloed van ervaring op koste en pryse word gekwantifiseer en bronne van die ervaringseffek wat hulle tot strategiese bestuur leen, word aangedui. Strategiese implikasies vir mededingende interaksie met benutting van maatskappy-ervaring word oorweeg. (Die tweede artikel, wat later verskyn, sal sommige van die mites wat met die idille geassosieer word, aftakel. Oorwinnings teen buitensporige koste in die soeke na groter markaandeel sal beskryf word, en praktiese probleme in die toepassing van die ervaringseffek sal ontleed word.)

S.Afr. Tydskr. Bedryfsl. 1982, 13: 101-112

First in a series of two articles

\section{Grant Robinson}

Senior Lecturer, School of Business Leadership, University of South Africa,

P.O. Box 392, Pretoria 0001, Republic of South Africa

Received April 1982

\section{Introduction}

Experience curves have received attention from strategists because they allow for estimates of existing and future company, competitor and industry segment cost patterns. They allow for quantitative estimates of cost behaviour and provide powerful guidelines for setting strategy in industries in which the experience curve exists. The curves, however, are by no means all pervasive and their ubiquity is, as yet, unproven. However, the Boston Consulting Group claims to have analysed experience curve relationships for virtually every client and do have a substantial body of evidence. Evidence both for and against is given.

The Boston Consulting Group has identified historical relationships which support the theory that declining real unit costs occur as cumulative production accrues. This hypothesis was developed to explain price and competitive behaviour in extremely fast growing segments of the chemical industry, polyvinylchloride, polyethylene and segments of the electronics industry, transistors and semiconductors. It provides a reasonable explanation for behaviour in those industry segments. The rationale behind the experience effect and some examples of experience curves will be critically portrayed in this article, and the relationship between experience, scale and learning effects explored.

Costs do not simply decline. Cost reductions must be managed and reasons for cost reduction are given.

Acceptance of the experience effect and the conclusion that market dominance, by way of obtaining and holding the largest share of a market segment is necessary, gives rise to a number of well-defined strategic moves. Guidelines are given with regard to pricing decisions, the erection of barriers to entry, competitor analysis and competitive behaviour, corporate profitability, segmentation, exit criteria and the allocation of scarce resources among products. The logic associated with strategy setting using the experience curve leads logically, via the inclusion of cash flow criteria, to the Boston Consulting Group's growth-share and growth-gain matrices. The application of the technique and various graphs and formulae are provided to aid in analysis and implementation.

Of great strategic importance is the fact that experience gains can be transferrred between products, provided the factors that are relevant and transferable between various businesses can be specified. ${ }^{1}$ High profits at the intersection 
of extensible core skills and market segmentation suggests that transferable experience effects can be fruitfully used in setting strategy in the manufacturing sector. ${ }^{2}$

Most applications of experience curves appear to have been found in the manufacturing sector, but increasing price competition within the services sector must provide incentives to explore the applicability of the concept there as well.

Lest the strategist be carried away, examples of a number of pyrrhic victories in the quest for market share are given. Practical problems in the application of experience curves to businesses, and the pitfalls which await the unwary are expanded upon.

\section{The experience effect}

The commander of the Wright Patterson Air Force Base noted, in 1925, that the number of direct labour hours required for assembly of an airplane decreased with an increase in the number of planes assembled over time. ${ }^{3}$ The relationship between output per labour hour, or machine hour, became known as the learning curve and became a useful planning tool in predicting industry cost behaviour patterns in the learning or start-up phases of production. 4.5,6 Various authors have pointed out that the learning phase was superseded by a steady state phase where no substantial additional gains in output were forthcoming. The tool was used in aircraft, chemical and some electronics industries to predict cost behaviour or to assess manufacturing performance. ${ }^{7,89,10.11}$

In the course of their consulting experience the Boston Consulting Group found that the relationship between cost and output was far more ubiquitous and extended to the total cost in manufacturing, distributing and selling a product. ${ }^{12,13,14,15}$ Simply expressed, the BCG found that:

Every time the cumulated experience in manufactur-

ing a given product doubles, the total unit value add-

ed cost, expressed in real terms, declined by a con-

stant and predictable percentage.

The relationship between cumulative experience, expressed as cumulated units of production, and value added costs, deflated to remove the masking effects of inflation, became known as the experience curve.

An experience curve is plotted in Figure 1. It shows the cost per unit declining in response to an increase in ex-

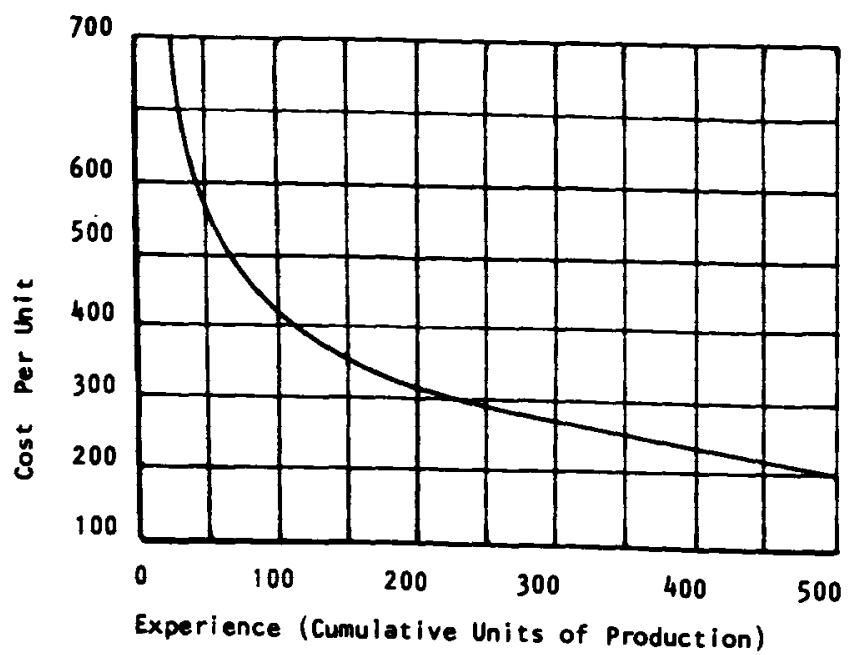

Fhare 1 A typical experience curve perience, expressed as total accumulated production. The curve shown is a ' $70 \%$ ' experience curve meaning that the curve is adequately described by the fact that every time experience doubles costs drop to $70 \%$ of their value prior to the doubling. A cost reduction of $30 \%$ is achieved. The $70 \%$ is not sancrosanct and other percentage curves, $75 \%$, $80 \%$, etc. exist.

The experience curve is described by the formula:16

$C_{t}=C_{t-i}\left(\frac{V_{t}}{V_{t-i}}\right)^{-\lambda}$

where:

$V_{t}=$ the experience, cumulative production, to date,

$V_{t-i}=$ the experience, cumulative production, at an earlier specified date,

$C_{t}=$ the present cost of a unit, adjusted for inflation, $C_{t-i}=$ the previous cost of a unit at the earlier specified date adjusted for inflation, and

$\lambda=$ an exponent characteristic of the learning rate.

Simply put, the ratio of experience at one point in time to another, earlier point, $V_{t} / V_{t-i}$, leads to a cost reduction in the ratio $C_{t} / C_{t-i}$ dependent on the value of the exponent. For a given exponent $\lambda$ the relative cost reduction is the same when doubling cumulative production from 1000 to 2000 units as when going from 100 to 200 units.

Various values of $\lambda$ are given in Table 1 for various experience curves. Table 2 gives some cost reductions owing to increased experience.

A logarithmic transformation of equation 1 yields

$\log \left(C_{l}\right)-\log \left(C_{1-i}\right)=-\lambda\left(\log \left(V_{l}\right)-\log \left(V_{1-i}\right)\right)$

This equation is now linear in the log of cost and the $\log$ of cumulative production. On this basis the experience curve is more easily expressed on log-log paper with logarithms on both the vertical and horizontal scales. Figure 2 shows the $70 \%$ experience curve from Figure 1 drawn on the double logarithmic scale.

Equation 2 can be expressed as

$\Delta \log ($ cost $)=-\lambda \Delta \log$ (cumulative production)

where $\Delta$ is the difference operator.

$\lambda$ is simply the slope of the curve, and the learning rate by which costs fall is easily found by ratioing any two costs associated with a doubling of cumulative production. For example a doubling in cumulative production occurs between 50 and 100 units on Figure 2. Costs are 44,0 and 30,8. The ratio is $30,8 / 44,0=0,70$.

The fundamental nature of this relationship makes it a useful tool for product management and for the development of strategy. Note that the effect of inflation is deliberately factored out using a national deflator such as the GNP deflator. The BCG advocates the use of the GNP deflator rather than a sectoral deflator, the reason being that use of a sectoral deflator in attempting to track real cost reduction in an industry may actually erase the evidence being sought. ${ }^{13}$

In instances where experience is accumulating at very high rates, such as the semiconductor industry, costs will 
Table 1 Value of the exponent $\lambda$ for various experience curves

\begin{tabular}{rccc}
\hline Experience curve & Exponent & Experience curve & Exponent \\
\hline $100 \%$ & 0,0000 & $75 \%$ & 0,4150 \\
$97 \%$ & 0,0365 & $72,5 \%$ & 0,4641 \\
$95 \%$ & 0,0764 & $70 \%$ & 0,5146 \\
$92,5 \%$ & 0,1126 & $67,5 \%$ & 0,5671 \\
$90 \%$ & 0,1522 & $65 \%$ & 0,6216 \\
$87,5 \%$ & 0,1927 & $62,5 \%$ & 0,6781 \\
$85 \%$ & 0,2347 & $60 \%$ & 0,7369 \\
$82,5 \%$ & 0,2774 & $57,5 \%$ & 0,7983 \\
$80 \%$ & 0,3219 & $55 \%$ & 0,8625 \\
$77,5 \%$ & 0,3678 & $52,5 \%$ & 0,9296 \\
$75 \%$ & 0,4157 & $50 \%$ & 1,0000 \\
\hline
\end{tabular}

Formula: $\lambda=(1-\log \chi) / 0,3010$ where $\chi=$ Experience $\% / 100$, e.g. for $70 \%$ curve $x=0,70$

Table 2 Cost reductions owing to increased experience

\begin{tabular}{crrrrrr}
\hline $\begin{array}{c}\text { Ratio of old } \\
\text { experience to }\end{array}$ & \multicolumn{5}{c}{ Experience curve } \\
\cline { 2 - 7 } new experience & $70 \%$ & $75 \%$ & $80 \%$ & $85 \%$ & $90 \%$ & $95 \%$ \\
\hline 1,1 & 5 & 4 & 3 & 2 & 1 & 1 \\
1,25 & 11 & 9 & 7 & 5 & 4 & 2 \\
1,5 & 19 & 15 & 12 & 9 & 6 & 3 \\
1,75 & 25 & 21 & 16 & 12 & 8 & 4 \\
2,0 & 30 & 25 & 20 & 15 & 10 & 5 \\
2,5 & 38 & 32 & 26 & 19 & 13 & 7 \\
3,0 & 43 & 37 & 30 & 23 & 15 & 8 \\
4,0 & 51 & 44 & 36 & 28 & 19 & 10 \\
6,0 & 60 & 52 & 44 & 34 & 24 & 12 \\
8,0 & 66 & 58 & 49 & 39 & 27 & 14 \\
16,0 & 76 & 68 & 59 & 48 & 34 & 19 \\
\hline
\end{tabular}

Formula: Reduction $=100\left[1-\operatorname{antilog}\left(-\lambda \log \left(\frac{v_{T}}{V_{T-i}}\right)\right)\right]$

For a $70 \%$ curve and a trebling of experience; $\lambda=0,5146$; $\frac{V_{T}}{V_{T-i}}=3$

Reduction $=100[1-\operatorname{antilog}(-0,5146 \log (3))]=43,2 \%$

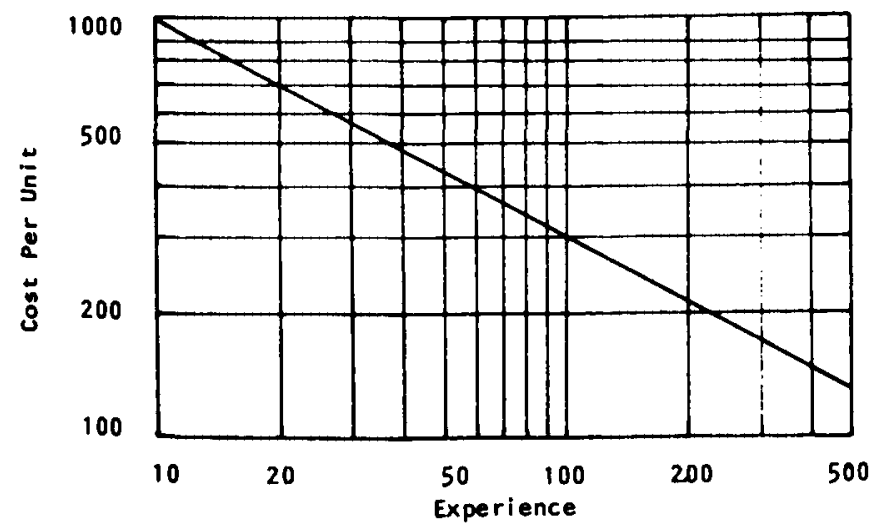

Figure 2 The $70 \%$ experience curve plotted on log-log scales be found to decline so strongly in absolute terms that it may not even be necessary to deflate the cost data to see a visible decline in costs with experience.

The relationship, strictly speaking, only holds for the value added component, (production cost less cost of materials, components and energy bought in), rather than the total cost of the product. This has strategic connotations, as discussed in the next article. Input components, raw materials and energy sources may, however, also evince experience effects of their own.

Cost data are usually proprietary and difficult to obtain for individual products, so research on the subject requires a high degree of cooperation and assistance on the part of manufacturers. Discontinuities owing to changes in accounting methods and the allocation of overheads have to be contended with.

The costs include all the cost elements which interact and trade off with one another. This means that costs of every kind required to deliver the product to the end user, including the intangibles which affect perceived value, must be included. This means that R\&D expense, sales expense, advertising, overhead and everything else should be included. This is where the experience curve differs from the learning curve which relates only to labour and production inputs. The experience curve quantifies the cost impact, and implicitly the cash flow effect, of all of the cost combinations owing to company activity.

\section{Examples of experience curves}

The Boston Consulting Group has produced straight lines on log-log paper reflecting the consistent relationship between experience and prices and experience and costs for a large number of products and industries..$^{12,13,14,15,16} \mathrm{Six}$ examples are given in Figures 3 to 8 . The cost data on steam turbine generators was obtained from US antitrust hearings. The Japanese beer data is from the BCG in Japan and the rest are from pulished sources. Theoretically the curve should show the relationship between product cost and company experience and many of the examples given by the BCG do so. As company data is usually confidential, the examples chosen tend to show industry price, in constant dollars versus industry experience. This is achieved by plotting the weighted average unit price, if several sizes or grades are involved, against total historical industry units.

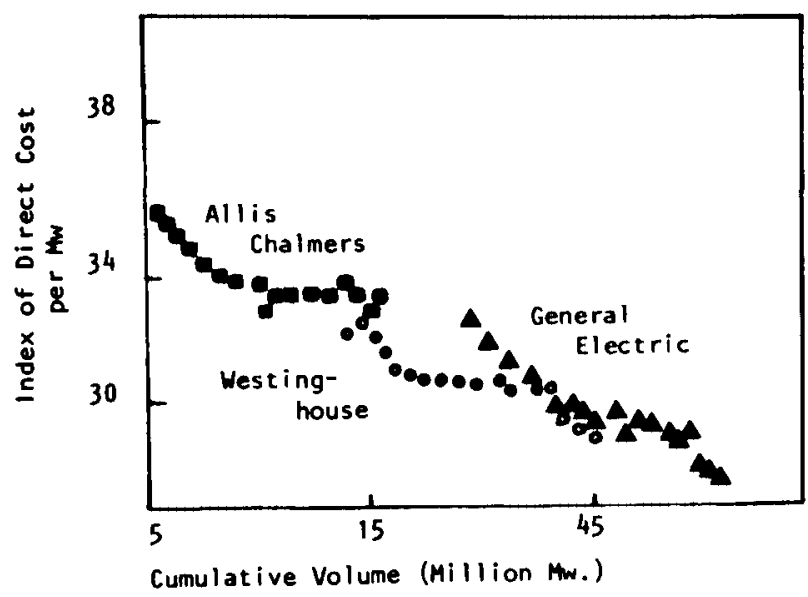

Figure 3 Cost of US steam turbine generators ${ }^{14}$ 


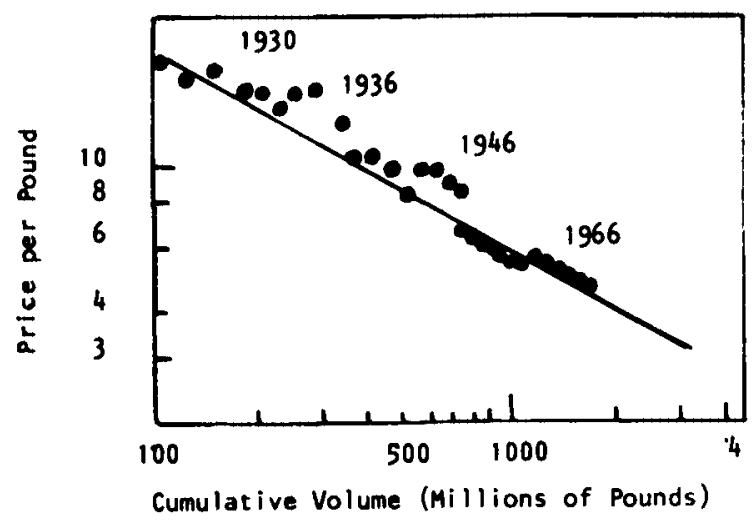

Figure 4 Experience curve for viscose rayon in the UK ${ }^{14}$

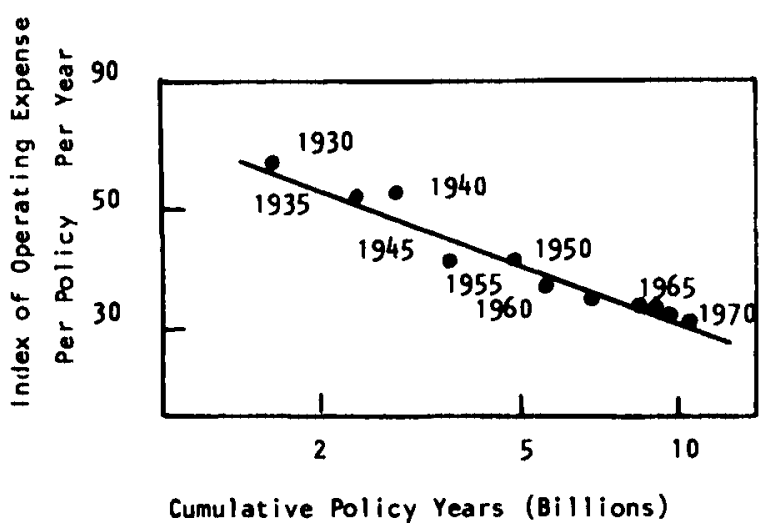

Figure 5 Experience curve for the US life insurance industry ${ }^{14}$

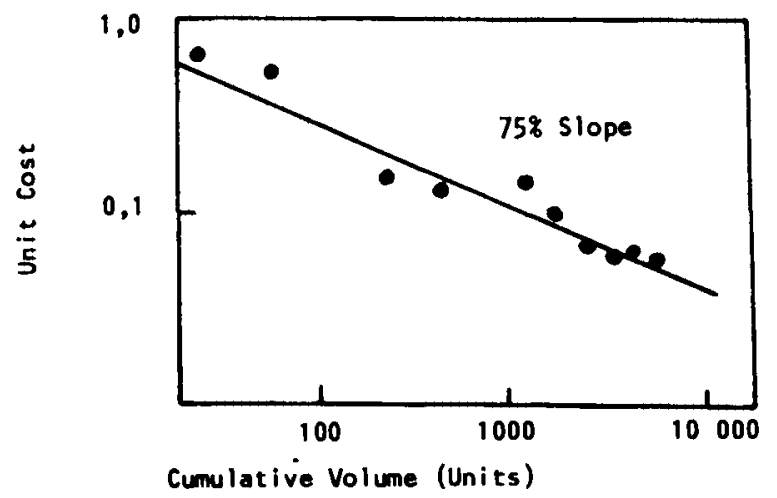

Fhure 6 Experience curve for an industrial plastic product ${ }^{14}$

\section{Scale effects, leaming curves and experience curves}

Economists, in particular, refer to the concept of economies of scale or scale effects. The scale effect, when applied to costing theory, is used by economists to explain barriers to entry owing to scale disadvantages. . $7,18,19,20^{2}$

In manufacturing and process industry the fact that it costs less per unit of output to build larger and larger capacity, provided it is technically feasible, has been recognized. The relationship is usually quantified on the basis that costs are related by the ratio

$\frac{C_{2}}{C_{1}}=\left(\frac{P_{2}}{P_{1}}\right)^{B}$

where:

$C_{2}=$ the capital cost of process equipment to produce $\boldsymbol{P}_{2}$ units,

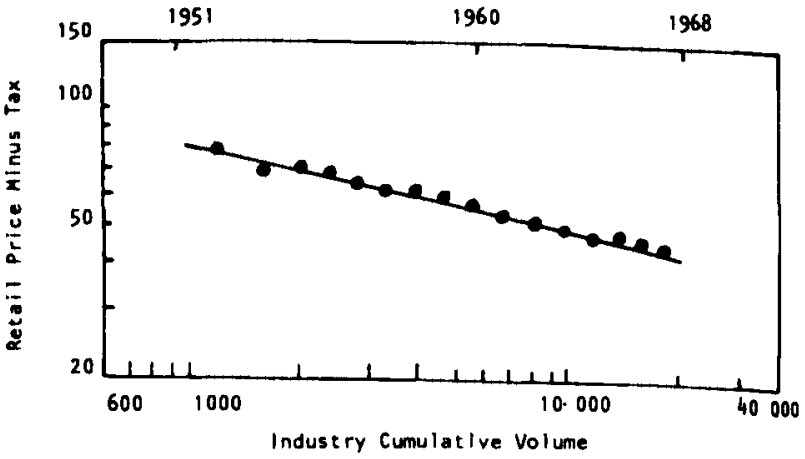

Figure 7 Experience curve for Japanese beer ${ }^{12}$

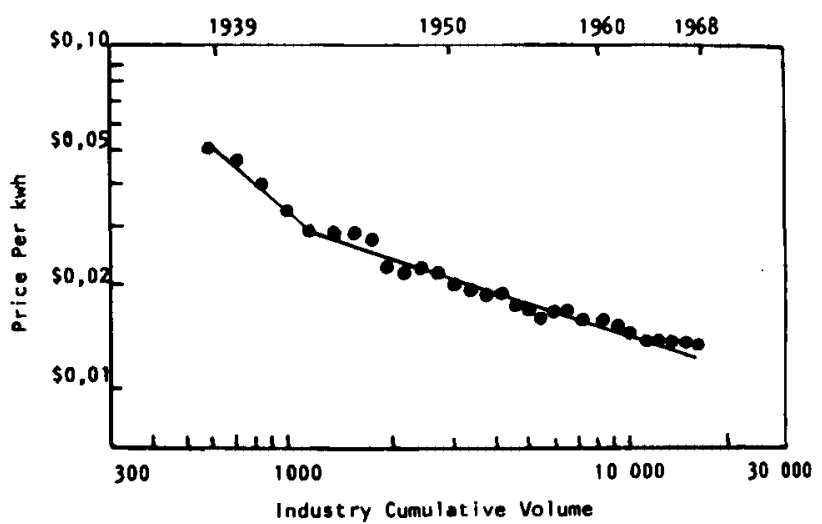

Figure 8 Experience curve for electric power ${ }^{12}$

$C_{1}=$ the capital cost of process equipment to produce $P_{1}$ units, and

$\beta=$ an exponent less than one and greater than zero.

Different values of $\beta$ have been empirically determined for various types of process or pieces of equipment. ${ }^{21}$

The usual value for $\beta$ is in the range 0,5 to 1,0 . For example, in the design of a large integrated process plant with a $\beta$ of 0,7 , the difference in capital cost between two plants, when one has twice the rated design capacity of the other, is likely to be:

$R=\left(\frac{2}{1}\right)^{0,7}=1,624$

The plant with twice the rated capacity should cost only about $62 \%$ more. The fixed cost per unit of output, assuming full capacity utilization and no other overheads, should then be only $81 \%$ of the smaller plants' costs.

There are usually additional savings. As equipment gets larger it usually becomes more automated, and the use of automatic control switching and monitoring equipment reduces the labour complement. Savings are effected on inventories of spare parts and intermediate storage. Specialization of operations and modularity of design and assembly procedures occurs. Automation of functional areas such as accounting, inventory control and production functions reduces unit costs.

Large-scale purchase discounts, increased bargaining power in the market place and savings in marketing, sales, advertising and R\&D owing to higher volumes with the same fixed costs can also occur. 
Some attempts have been made to isolate scale effects on unit costs in order to test ideas on industry profitability, barriers to entry and seller concentration. . $^{19,22,23}$

Observations on unit costs can be made, especially at the design stage and as related to fixed overhead. Observations can be made with the regard to efficacy associated with pure scale for functional areas, such as marketing. Empirical testing of existing company information proves it difficult to separate out the two effects. This arises partly from the fact that as companies accumulate experience they add capacity to match demand and become larger. The two effects merge into one.

Similarly, it appears that the learning curve is a subset of the experience curve and concerns itself with the early start-up phases of a business. The French, with Gallic charm, refer to long-run and short-run experience curves. The experience curve encompasses all costs, including capital, administrative, production, research and marketing, and traces them through technological displacement and product evolution. ${ }^{12}$

\section{Sources of the experience effect}

The Boston Consulting Group considers the experience effect to be a total manifestation of the way a company goes about its whole business. This implies that improvements in functional areas, in environmental change in social, political, legal, technological, economic and labour areas, in fact everything that goes to make up the business, contributes to gaining experience. A number of factors have been identified as contributing. ${ }^{14,16}$ Many others may exist.

\section{Technological change}

Productivity improvements owing to technological change, the adoption of new production processes and tooling, the use of mass production, and the innovation of production techniques generate cost reductions. Texas Instruments, for example, allocates a large percentage of resources to the pre-emptive replacement of plant and equipment designed to handle the rapidly-evolving semiconductor industry and has devoted a major effort to the development of advanced integrated circuit manufacturing equipment. The new equipment often has very high productivity, with new machines being able to produce in excess of $15 \%$ of the world's requirements for a given product. The impact in an industry growing at over $60 \%$ per annum means that in each year the newly added capacity is over one half of the industry's previous total capacity. ${ }^{24}$

\section{Improved job design}

Major experience gains can be attributed to improved job design and specialization. Specialization by the correct specification of individual tasks, the method of performing the task and the combination of individual tasks into specific jobs to be assigned to individuals, yields gains. ${ }^{25}$ Individual tasks can be designed for specialist skill requirements which are both easily and quickly attainable. Workloads can be equalized and layouts can be tailored to worker needs. Participation in decision-making, product standardization, inter-changeability of parts and plannings of operations at work stations guard against repetitiveness and boring operations.

\section{Scale and learning effects}

Improvements in labour dexterity and methods lead to improvements in all the functional areas from production, through finance, marketing and so on. Scale effects accrue as the process gets larger to supply increased volumes.

\section{Process redesign and optimization}

Less efficient factors of production are systematically displaced. Investment in cost reductions are specifically undertaken, such as substituting capital for labour. Plant bottlenecks are identified and innovative ways of improving plant output are found, such as autogenous milling instead of ball milling in mineral extraction, or optimal temperature and pressure combinations for chemical reactors.

\section{Product standardization}

Product standardization by the use of modular components is practised by some car and motorcycle manufacturers, where common components such as engines and transmissions gain experience benefits from volume, but are still amenable to being assembled into a wide range of models.

\section{Product redesign}

Greatly enhanced product performance and simplicity of manufacture are due to improvements in design and the use of new components or materials to improve performance or cut costs.

\section{Quality circles}

The conscious use of techniques such as quality circles to continually enhance performance and reduce downtime has been very successfully applied by the Japanese..$^{26} \mathrm{After}$ being acquired from Motorola, the Matshusita Chicago plant manufacturing the Quasar television set reduced faults per 100 sets from 150 to 4 with an obvious impact on costs. Numerous other examples exist.

\section{Management of working capital}

By careful attention to working capital requirements the Japanese have been extremely successful in reducing capital intensity and, as a result, corporate overheads. Suppliers carry out multiple drops per day on production lines to reduce inventory holding costs. ${ }^{27}$

\section{Strategic operations planning}

Extremely impressive cost reductions are forthcoming when issues normally considered as operational and consequently abdicated down the line, are analysed for their strategic impact. By attention to strategic detail, implicit in operating decisions, Sanyo Electric between 1975 and 1980 were able to double sales volume, cut warehouse space by $75 \%$, inventories by $85 \%$, lot sizes by $66 \%$, triple production quantities, triple the models being made and improve profits to $729 \%$ of their 1975 levels. ${ }^{27}$

It is by no means unusual to find managers who do not believe that continuous real cost reductions can be achieved over time. Companies can be found in which the real cost performance has been increasing. Cost reductions are not automatic. They have to be aggressively managed downwards. Poor operating controls, inadequate reinvestment in new methods of cost reduction, build up of 
unproductive overhead or investments in managerial ego can all lead to adverse cost performance. Texas Instruments includes in its statement of company policy the words 'focus on continuing cost reduction and productivity improvement'. This is seen as an alternative to government protection or the erection of tariff barriers. The company expends effort on finding the areas where cost reduction can be achieved. ${ }^{24}$

It ' is often easiest to find means for real cost reduction in high growth businesses. Production scale is expanding and there is plenty of scope for the introduction of new technology and labour saving production methods without redundancy programmes, which are a problem in industries in countries like the UK. ${ }^{14}$ Many opportunities arise to reduce the level of the more slowly-declining cost components of the total mix.

\section{Costs, price and experience}

The rate of growth of cumulative production is an important factor in understanding experience curves. For nogrowth markets the percent increase in total experience and hence the decrease in costs slows down and tends to zero. Consider the case where production is 1 unit per year and does not increase. Cumulative production for years 2,3 , 4 , etc. will be $2,3,4$, but the percentage increase on the previous year is $100 \%, 50 \%, 33,3 \%$, etc. This is illustrated in Figure 9.

When volume of production grows by a constant yearly rate, say $15 \%$, it can be shown ${ }^{12}$ that the levels of experience tend toward the growth rate, $15 \%$ in this case, and successive positions on the log plot appear evenly spaced as shown in Figure 10.

When there is no change in relative market share and competitors are growing at one another's rates, which is the industry rate, then in the equation

$$
C_{t}=C_{t-i}\left(\frac{V_{t}}{V_{t-i}}\right)^{-\lambda},
$$

the relative volumes $V_{t} / V_{t-i}$ are the same for all competitors and hence the relative costs $C_{t} / C_{t-i}$ are the same. The relative cost improvement for each competitor is the same and they all move down the experience curve at the same rates as shown in Figure 11.

If different competitors follow different experience curves, or if changes in market share are occurring, the respective costs will move relative to one another.

The Boston Consulting Group contends that prices follow the same pattern as costs if the relationships between competitors is stable. ${ }^{12}$ When prices do not fall with costs, the competitive relationship becomes increasingly unstable and major changes in market position can occur.

A typical stable cost and price pattern is shown in Figure 12. An initially low price, below initial production cost to enter the market, is held until the company breaks even and makes a profit, after which prices move parallel to costs. This type of pattern tends to be found in high growth technology-intensive industries such as integrated circuits.

The profit margin as a percentage of the total selling price remains constant. This type of pricing strategy has been adopted by companies such as Texas Instruments and

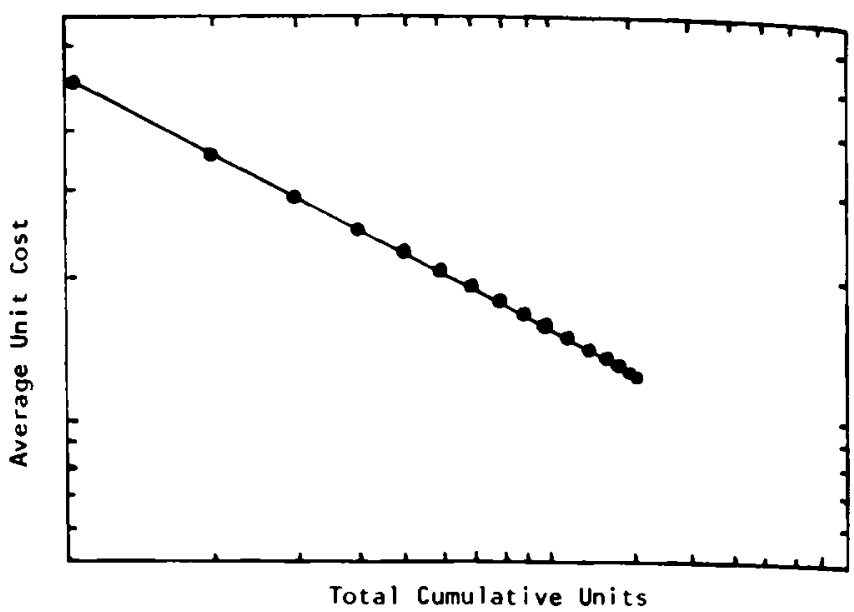

Figure 9 The effect of no annual growth in physical volume on the rate of decrease in unit cost ${ }^{12}$

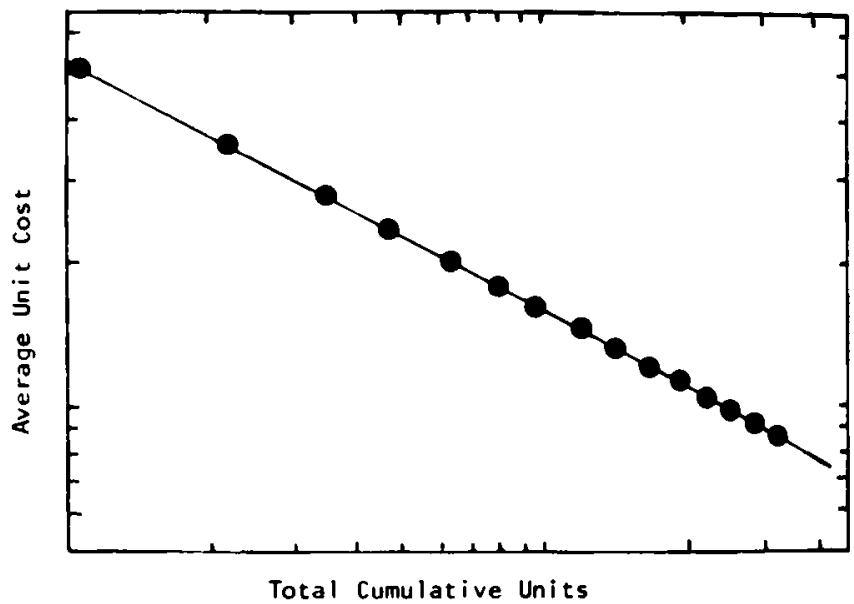

Figure 10 The effect of a constant rate of growth in physical volume on the average unit cost ${ }^{12}$

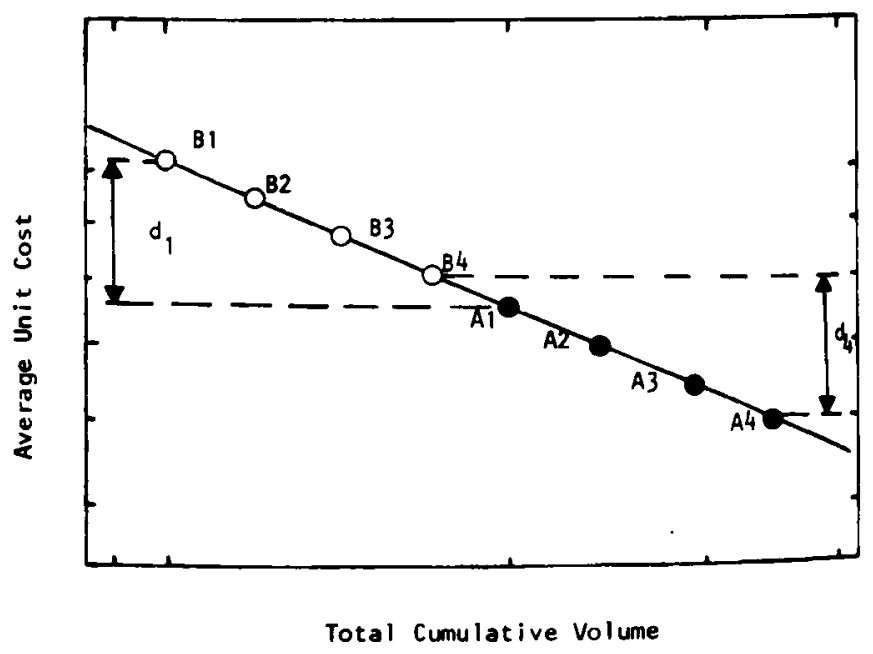

Figure 11 If accumulated experience ratios stay the same, so do relative costs expressed in percent ${ }^{12}$

IBM, and tends to discourage competitive entry if margins are kept to reasonably moderate levels. As such it can constitute a barrier to entry.

This type of pricing behaviour should be used in monopolistic or near monopolistic conditions. It not only discourages competitive behaviour, but also wards off moves to introduce legislation that would otherwise have been enacted if a company were seen to be making extortionate profits.

A tendency to letting prices decline slower than costs, thereby increasing margins, does arise (Figure 13). 


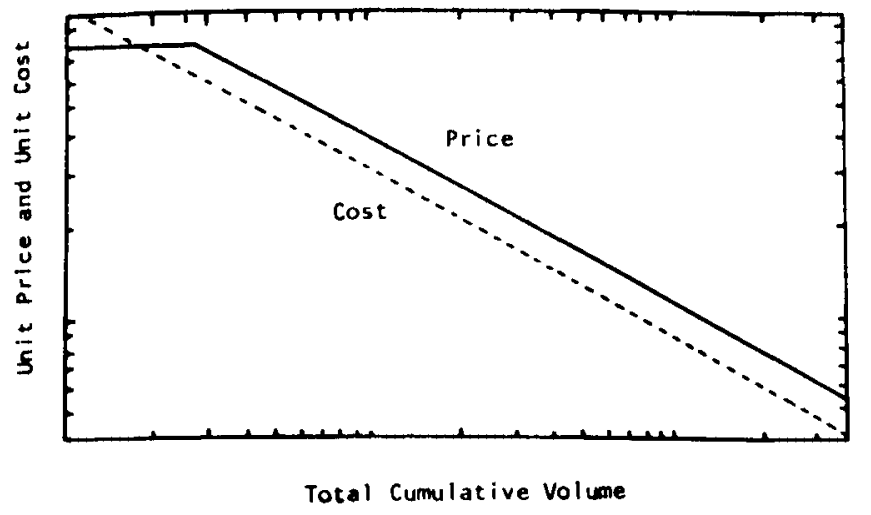

Figure 12 A stable pricing pattern ${ }^{12}$

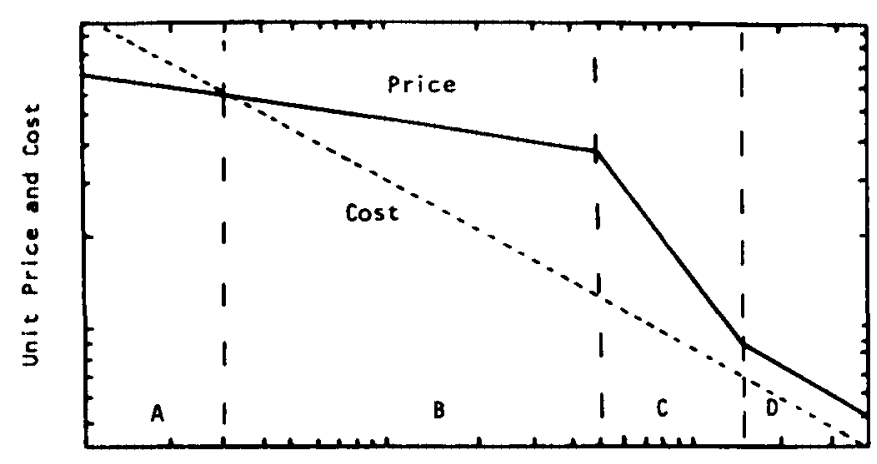

Total Cumulated Volume

Figure 13 Dynamics of price instability and stability ${ }^{12}$

A Introductory phase B Price umbrella

C Shakeout D Stable pricing

Prices are set below cost initially to establish a market in the introductory phase. As volume grows and costs decline with experience, price does not quite follow. A price umbrella is formed and margins improve substantially. The market leader is often responsible for holding a price umbrella over higher cost producers who are increasing their market share. The dominant producer is trading future competitive position for current profits. This invites competitive entry and prices drop faster than cost under the quest for market share. The new entrants, or aggressive existing competition, consider their optimum strategy to be to lower prices faster than industry costs are declining. The instability associated with the price umbrella stage is greatest when market growth is rapid and there are many producers, and the difference between cost and price is large, even for the high cost producers. The instability is heightened when the initiator of the price break recognizes two conditions.

- the demand elasticity is such that marginal revenues are greater than marginal costs for the given producer at that time, and

- the added cumulative volume allows the price break initiator to reduce his own costs faster than industry costs are decreasing on balance, provided he can increase market share quickly enough.

During this shakeout phase many of the competitors are eliminated and the market leader is often replaced.

The Boston Consulting Group points out ${ }^{12 . p .22}$ that the instability becomes such that any chance event can precipitate the shakeout phase. Their graphs indicate that breaks have been precipitated by several triggers, and they have identified the following as some initiators:
- Recession. Mild recessions triggered breaks in semiconductor and chemical products.

- Attempts to buy market share either by a new entrant or an existing producer, often a dominant producer who has sustained the price umbrella.

- Overcapacity in the market owing to new entrants attracted by the price umbrella.

After the shakeout, stability begins to emerge in the market and the relationship of cost to price becomes reestablished, often with a different dominant competitor to that under the price umbrella.

Unstable patterns for germanium and silicon diodes are shown in Figures 14 and 15. The pattern is repeated for germanium transistors and silicon transistors in Figures 16 and 17. All of the products concerned are discrete semiconductor devices used in industries such as the calculator industry. There is a high degree of substitutability between the devices, and it should be noted how closely the price breaks correlate with one another. By contrast, integrated circuits has a stable pricing pattern (Figure 18).

\section{Competitive Interaction}

If a significant proportion of cost is directly attributable to the added value given to a product then, in industries where this cost can be reduced either by scale or experience, or both, tremendous cost advantages can be gained by pursuing a strategy targeted at cumulating experience faster than the competitors.

Two scenarios can be envisaged:

- one in which the competitors are moving down different experience curves with different slopes (see Figure 19), or

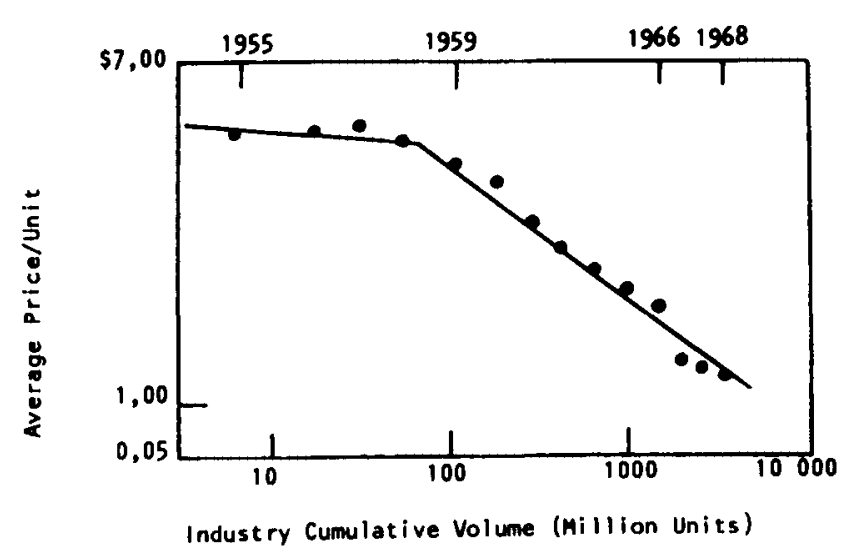

Figure 14 Price volume relationship for silicon diodes ${ }^{14}$

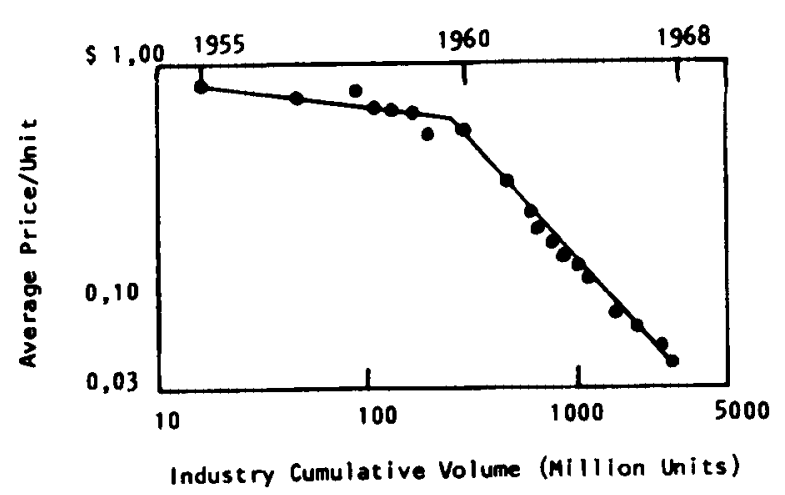

Figure 15 Price volume relationships for germanium diodes ${ }^{14}$ 
- one in which the competitors are moving down the same experience curve or curves with similar slopes at the same rate (see Figure 20).

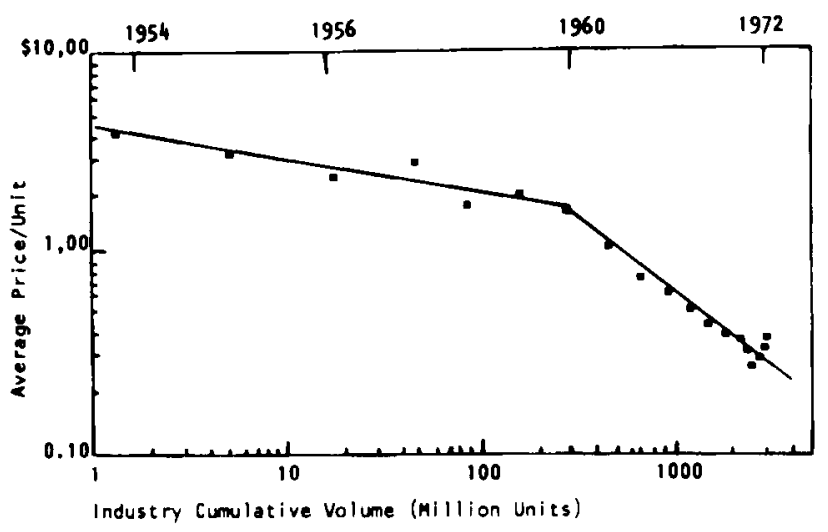

Figare 16 Experience curve for germanium transistors ${ }^{14}$

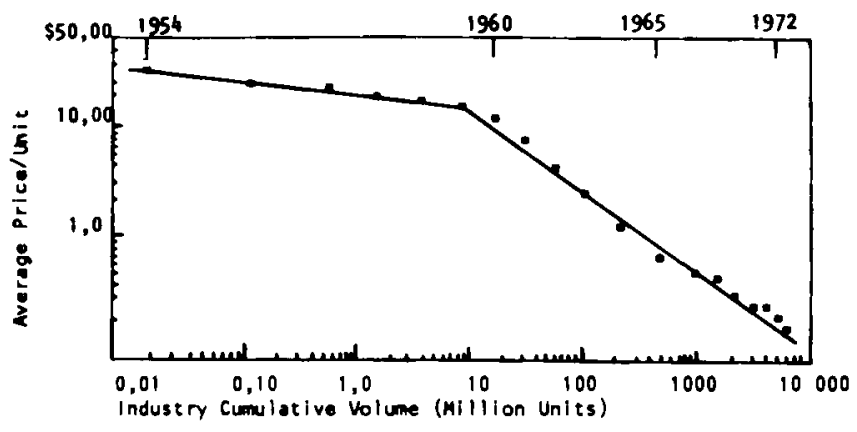

Figure 17 Experience curve for silicon transistors ${ }^{14}$

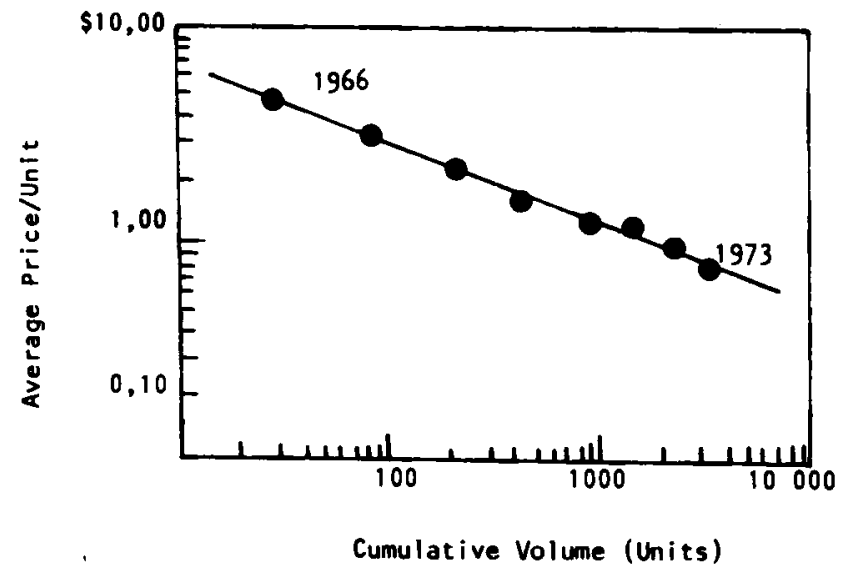

Figure 18 Experience curve for integrated circuits ${ }^{14}$

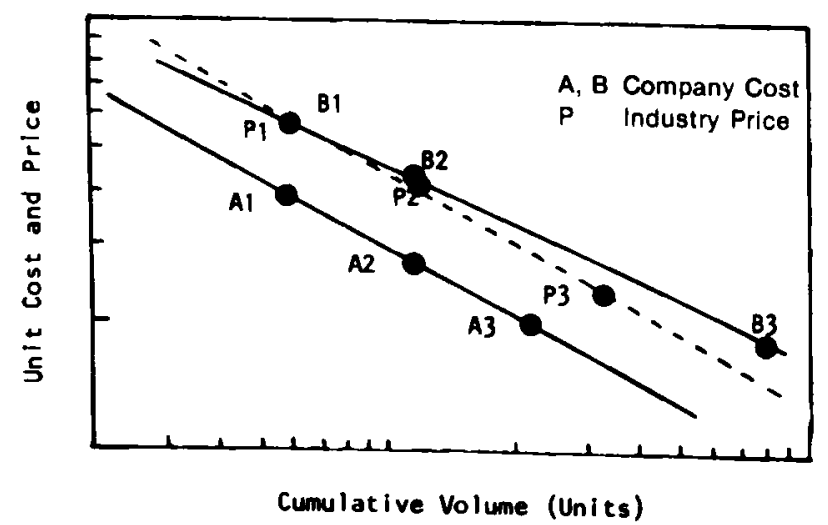

Figure 19 Compensation for inferior experience curve effects by increasing market share

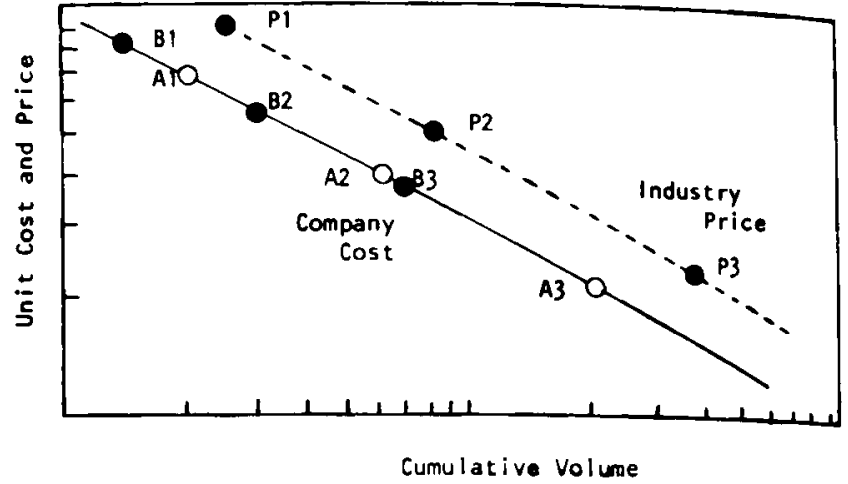

Figure 20 Increasing non competitiveness owing to slower rate of improvement down the experience curve

In Figure 19 the two competitors are moving down different slopes. Company $B$, operating at breakeven at $B_{1}$, cumulates experience to $B_{2}$, which cost is above the industry price structure. Costs are not reduced as quickly as the more efficient competitor $\mathrm{A}$ and the effect of cost experience accrues to $\mathrm{A}$ even with equal increases in cumulative experience. Competitor B can still compete if he accumulates experience faster than competitor $A$ by moving proportionately faster down the curve to $B_{3}$ contrasted to $A_{3}$ and steadily increasing market share. Company B offsets company A's efficiency by moving more quickly down a less steep cost reduction slope. This cannot occur for too long, especially if market growth rate slows down or if market shares become large, thus reducing their relative impact.

The introduction of a price umbrella and shakeout merely serves to postpone the inevitable. When both competitors are moving down the same, or similar slopes, one company, say B, may move down the slope more slowly than the other company owing to decreasing market share. Two things can occur (Figure 20). Firstly, B's position can continue to deteriorate inexorably as $B$ loses market share and cumulative experience and becomes increasingly less competitive, and finally the liquidators move in at costs $B_{3}$ and $A_{3}$. Secondly, the relationship between the competitors can stabilize at essentially constant market shares but at very different profit margins. Under these circumstances the less competitive company accepts a reduced margin and market share. The price level is influenced by the highest cost producers' price required to grow fast enough to maintain market share (Figure 21).

The companies whose costs reduce most quickly will obviously replace those whose costs go down more slowly. Gains in market share are directly translatable into cost reductions. Products in generic competition are subject to the same laws of the market place as evinced by the behaviour of germanium and silicon diode costs, Figures 14 and 15, and germanium and silicon transistor costs, Figures 16 and 17. It should be noted that a major technological innovation coupled with a fast growth rate down an experience curve can spell doom for an outdated technology in an industry where the innovation leads to substitution for an existing product. The critical determinants are always the requirements of the strategic market segment rather than a generic product name.

The implications are:

- if all competitors keep to the same relative experience 
then cost differentials and margins should remain the same

- if any competitor reduces costs more slowly than the industry average he will become non-competitive

- increases in market share are directly translatable into the equivalent relative cost advantage.

\section{Strategic implications}

The strategic implications of the experience effect are fourfold:

- strategic cost reductions

- the need for market share

- the use of strategic market segmentation to combat a poor market position

- the use of shared experience.

As pointed out, real costs have to be controlled and ag. gressively managed downward. Good operating controls, investment in new methods, control of non-productive build up and the pruning of lagging products is required. It is easier to introduce new technology and labour saving devices when growth is high, rather than in slow growth industries. This precludes the need for redundancy programmes, often a problem in UK industry. This implies that industry structure (the Japanese Zaibatsu as compared with the western models) could also affect the ability to manage costs.

The second implication of the experience curve effect is that, even given good cost control, profitability over the long term will be directly related to market share. This has been confirmed by the PIMS basic findings and has also been identified as the critical success requirement in a study of European acquisitions. ${ }^{28,29}$ Although it is difficult to find explicit cost and share data for a number of competitors in a given business, Figure 3 shows the comparative costs for US steam turbine generators. General Electric, the largest competitor, had the lowest unit costs per megawatt of capacity at any point in time followed by Westinghouse and then Allis Chalmers. Market shares and relative costs have remained stable and General Electric was considerably more profitable than Westinghouse, who in turn were more profitable than Allis Chalmers. In spite of Allis Chalmers achieving cost reduction over time, they could not catch General Electric unless relative market share positions were changed. This is a perennial business problem for Allis Chalmers.

Figure 21 illustrates the case of an industry with three firms. A has a signifcant cost advantage over $B$ who in

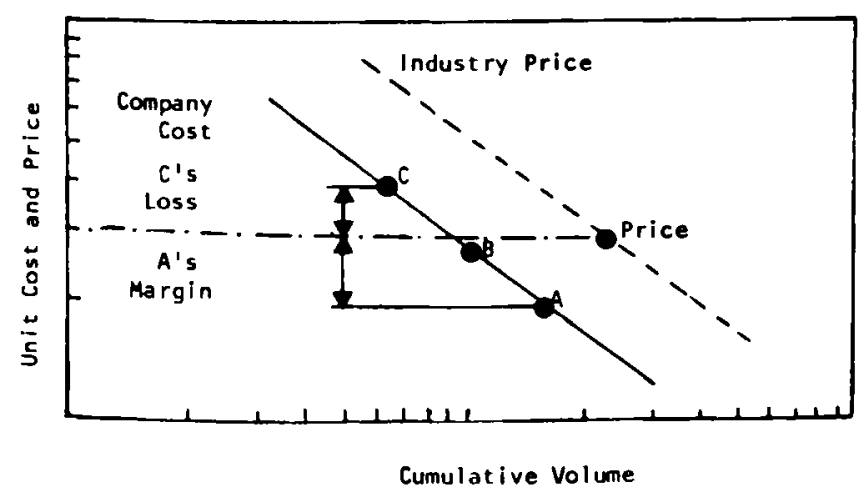

Figure 21 The advantages of greater market shar turn has a significant cost advantage over $C$. The leading competitor A can greatly influence the profitability of the other competitors by his pricing tactics. A could price aggressively as shown, and begin to drive out $\mathrm{C}$ by pricing below C's costs. Instead of driving out inefficient competitors, A could elect to decrease prices more slowly than costs are declining and thereby improve margins. While this strategy appears attractive to the market leader, it has the effect of improving the margins for the lower cost producers by a far larger percentage. Improved margins enable them to finance inroads into the dominant producer's market share. This upsets the competitive equilibrium, drives prices down and erodes the leader's relative cost advantage. It is a liquidation of the leader's position.

The fact that the change in margin for the low cost producer represents a far larger percentage change for the high cost producers means a tremendous inducement for them to try to increase market share. This creates an unstable situation and can precipitate a shakeout. Prices decline with costs in stable situations. This makes dismal reading for the low share competitors, but seems to be verified by numerous studies. 12,13,14,28,29

Figure 22 shows a low growth industry, the American car industry, and the relative profitability of General Motors, Ford, Chrysler and American Motors. The four companies form a very clear pecking order in terms of size and profits. The Japanese motor industry has a closely similar pattern which is also shown.

Figure 22 also shows the profitability of the major Japanese producers. Two lines can be drawn, one representing the relative profitability of the Japanese producers and a second that of the American producers. American Motors is a strange outlier, perhaps owing to the less integrated production process used in which many components are brought in, hence benefiting from other people's experience or a segmentation advantage over the other major US producers. In any event American Motors still has lower profitability than the other three majors. For both industries the strategic implications for a low share producer must be resignation to low profitability as long as market share remains low.

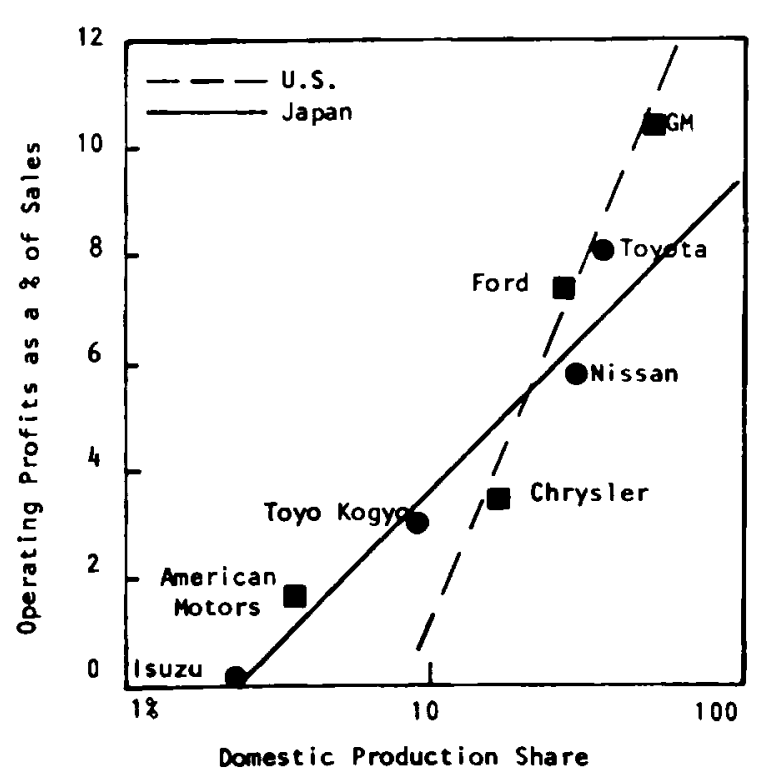

Figure 22 Profitability of the USA and Japanese motor industries ${ }^{14}$ 
Profit margins at market equilibrium are a function of two factors:

- The relative cumulated experience which determines the cost differential between the competitors. The leader will be most profitable but conversely, changes in profitability will be greatest, in percentage terms, for low cost producers.

- The profit margin required by the dominant producer to maintain position.

A revenue optimizing strategy must be pursued by the low cost producer and it should be related to the average for the industry. An upper level for price must be established that would induce the high cost producer to fund growth in market share. A lower limit for price must exist compatible with the lower cost producers' need to maintain market share, to fund growth and to pay dividends. It should occur when marginal investment in market share no longer produces marginal revenue.

The cost reduction principles above are relevant for the secondary producers. Firstly, an understanding of the competitive cost price dynamics defines the rules of the game and provides an understanding of how to outplay the market leader should he let his guard down. It also provides a framework for identifying when the market leader's guard is down. Secondly, if the low cost producer plays his end game skilfully he is almost unassailable. 'Try harder' and 'the one big break' strategies are not in general successful. The secondary producers should appraise their position and decide as to whether their existing profitability is satisfactory. If not, the alternatives appear liquidation or strategic market segmentation.

The PIMS studies, while validating the value of market share, do offer some hope in terms of a multidimensional instead of a univariate, strategic universe. ${ }^{30}$ Some of the issues are covered later under practical problems associated with applying the experience effect, pyrrhic victories in the quest for market share and the issue of strategic segmentation.

Accumulated experience is not the same as market share. If market share ratios are relatively stable, then accumulated experience ratios approach that of market share. Because of his low initial volumes, a late starter can move down the curve faster than the existing producers because of the compounding effect on the low initial volumes. The late starter, however, is unlikely to approach the level of the market leader until his accumulated experience begins to approximate that of the market leader. If two competitors enter a market at the same time, the relationship between them tends to be very unstable owing to the advantage to be gained in cost differential by increasing share.

This instability is compounded by the low cost of buying market share in the early stages of the life cycle and the fact that a competitive edge, if gained early on, would be rewarded by improved cost differentials and high volumes as the market matures. There is a compelling incentive to use both price and non-price forms of competition as a weapon to gain share.

Efforts to pre-empt a large share of the market can usually only be made:

- by companies with extremely large resources, or

- by companies in markets where competitors, wittingly or unknowingly, are willing to trade future margins for current returns.

Tremendous capital requirements and negative cash flows are required to both prune margins and invest in capacity. This requires substantial resources. The implications for pricing are:

- the final market equilibrium will be determined by the pricing behaviour of competition, particularly by the early entrants.

- market share and pricing policies should not be viewed in a short-term tactical light, but on the basis of present trade-offs versus future margins.

An optimum initial price must exist which may be below the initial cost of a new product offering. The price must be low enough to find a market. In price sensitive markets the development of the market can be forced and the time required to get volume up and price down can be compressed. Market elasticity increases the total impact by increasing the total market as well as market share.

Rather than trying to break even too soon, if a new product has potential for sufficient volume, the future competitive cost differential should be of more concern than current profitability. A low initial price builds up volume and a differential cost advantage over competitors. It also encourages market development. This is really the purchase of a time initiative. However, the lower the price the greater the resources required to fund the growth and the longer before a profit will be realized. The comparative investment resources of competitors can become a significant, or even critical, determinant of survival. It could extend the resources and even bankrupt the firm. In addition, the longer profits are deferred and the larger the investment, the greater the effect on the discounted present value of future profits. It should be possible to find an optimum provided the growth of the market could be forecast with sufficient accuracy.

However, the future growth of a market is often uncertain and initial prices tend to be set on the basis of initial costs by the first entrant. As volumes build up and costs decline, new entrants are invited into the market. The market leader then has a classic problem in choosing be tween current profitability and future market share.

It is also impractical or expensive to take physical volume away from a competitor. It is easier to take the differential growth in market size away from the competitor. Once the market matures and volumes stabilize, entry becomes difficult and costly.

In summary, new product pricing is critically important as it determines future competition, margins and product growth rates. For products with large potential markets, penetration must be more important than near term profitability.

If costs do follow a reducing pattern then:

- the producer who fails to reduce costs along the cost/volume slope will become uncompetitive

- the producer with the largest cumulative market share for a product should be able to maintain the leading edge associated with lowest cost

- new products should be sold at below cost until volume builds up

- under the effect of competition prices should go down as rapidly as costs

- the creation of a price umbrella invites competitive 
entry into a market

- market share is unstable until one producer clearly dominates the market and keeps his prices low enough to inhibit growth in market share by other significant competition

- market share is most easily gained in the high growth phases of a market

- capturing market share in growing markets can be costly in the short run

- pursuing market share in mature markets is costly and generally not worthwile

- if a new market is potentially large and attractive, substantial investment should be made in market share

- the secondary competitors in a market must reappraise their margins and either liquidate or go for strategic market segmentation.

\section{Strategic segmentation}

It is possible to be profitable by following a carefullychosen segmentation strategy rather than a market dominance strategy. For example, British Leyland between 1970 and 1973 with average sales of $£ 1261$ million had an operating profit margin of $4,1 \%$ compared to Ford (UK) with a margin of $4,8 \%$ on sales of $£ 716$ million. The answer lies in an analysis of the various car manufacturers' basic product offerings. ${ }^{12}$ Ford had four distinct models while Leyland had 19 distinct product offerings. (Vauxhall and Chrysler had three each.) The astounding breadth of Leyland's product line is partly a legacy of the way in which Leyland was formed by merger but it illustrates a number of key issues:

- the volume per product line for Leyland was low

- there was little rationalization of design across product lines

- although shared experience must help all products, the lack of commonality between different products in different market segments must affect the transfer of shared experience

- the low levels of volume per model puts a strategic limitation on the cost levels which can be attained, even given good labour relations, smooth production operations and competitive manning of the industry. ${ }^{12}$

An answer is to develop a competitive strategy specifically designed for the needs of a carefully identified target market segment and to dominate the given segment. Multisegment offerings can be made, in order to dominate the industry, if the products are rationalized and able to make use of shared experience via common components and modular design, for example the BMW 500 and 700 series or the Mercedes Benz $S$ series and $E$ series cars. The result is greater volume per model either through increased market share, or rationalization, or both. Rolls Royce with a turnover of only $£ 60$ million shows a pre-tax return of over $20 \%$. Lotus with a $£ 10$ million turnover is even more profitable.

Segment-based profitability can be risky, but it is the only approach a small manufacturer can use if he is to survive profitably. This seems to be the case in the United States, which, far from being the haven of big business, has enormous numbers of small specialized companies catering for some or other market niche segmented on any of a myriad of vectors ranging from geography to ethnicity.

Ideally the more secure route to profitability must be to dominate the market both on a segment and a total basis and to be the largest producer per unit volume per basic product type.

This indicates a need for explicit examination of the target market segments before applying the experience curve concept in setting strategy. Most broad business areas do break down into target market segments which have distinct economies. Guidelines on defining the target market segments have been evolved. ${ }^{32,33}$ This requires a detailed examination as to exactly what constitutes the criteria for the business; geographic for a brewery, international for semiconductors. It involves examining the basis for segmentation plus an analysis of each element of cost and value added and relating the basis on which an experience based on advantage relevant to the competition could feasibly exist in the given segment.

Summarizing, the overall aim of the segmentation exercise must be to identify product market segments which are distinct both economically and competitively, and then to develop a strategy for the segments as individual businesses. This means that the segmentation basis must include an experience curve effect on which a superior cost position can be developed for the segment. Often the relative market share in the segment alone may not be the sole determinant owing to shared or other experience effects. This means that gains in a smaller segment can be made by effectively focussing on those component costs amenable to shared and other experience as modified for the particular segment's needs.

\section{Conclusions}

In an industry driven by the experience effect, strategic implications of a gain in market share can be quantified in advance. Sources of the experience effect can be identified and actively managed downwards. Pricing in an industry can be seen to be profoundly strategic in nature and its impact amenable to forecasting.

The dilemma for the South African business manager rests upon the identification of whether a curve exists in his industry or not. This will be covered in the next issue of the journal. Considerations in applying the experience curve effect are also given.

The key issues for government planners are:

- the long-term strategic impact of trade and tariff barriers, and

- myopia associated with anti-trust legislation in the face of the Japanese challenge.

In developing nations the tendency has been toward the erection of trade and tariff barriers in order to protect fledgling industries. Buffered from external competition the young industries:

- grow slack and fat and don't manage costs aggressively down the curve, and

- move far more slowly down the curve, owing to the small volumes in protected markets, in comparison with large international competitors.

At some stage government is tempted to drop the barriers and suggest that the mollycoddled infant go international. Unless protected by a high technology core or a product line sufficiently differentiated to take advantage of 
strategic market segmentation, the young entrant faces impossible odds. The answer for many developing nations appears to be in the highish technology segments rather than in undifferentiated capital-intensive industries governed by a learning curve.

Similarly democratic ideologies masquerading under the guise of free competition can be equally damaging. If democratic nations allow the emergence of large numbers of competitors in a market which, if unprotected by barriers, cannot even support a single producer, then they must be crucified on the cross of their strategic mistakes. Multiple television producers, motor car manufacturers and so on are an indulgence which few nations can afford. Likewise the prevention of rationalization in an industry, or feeble attempts to bolster up already uncompetitive firms with national funds, can be deleterious in the long term, to which the British motor car and motorcyle industries bear witness. Even an international giant like the United States cannot long fund the indulgence of anti-trust legislation as little yellow businessmen take advantage of America firms hampered by such laws, and ride the experience curve with glee.

In experience curve industries the key to setting strategy must be strategic market segmentation followed by predatory price cutting to create barriers to entry, to gain market share and thereby to decrease costs.

\section{Reforences}

1. Rutenberg, D.P. What Strategic Planning Expects from Management Science. Working Paper No. 89-75-76, CarnegieMellon University, 1976.

2. Rumelt, R.P. Diversity and Profitability. Working Paper No. MGL-51, Los Angeles: University of California, 1977.

3. Wright, T.P. Factors affecting the cost of airplanes. J. Aernaut. Sci., Vol. 3, Feb. 1936, pp.122-128.

4. Summers, E.L. \& Welsch, G.A. How learning curve models can be applied to profit planning. Manage. Serv., Vol. 7, No.2, pp.45 - 50 .

5. Baloff, N. \& Kennelly, J.W. Accounting implications of product and process startups. J. Accounting Res., Vol.5, No.2, pp.131 - 143.

6. Baloff, N. \& McKersie, R.B. Motivating startups. J. Bus., Vol.39, No.4, pp.473-484.

7. Billon, S.A. Industrial time reduction curves as tools for forecasting. Ann Arbor, Michigan University, Microfilm, 1960.

8. Hirschmann, W.B. Profit from the learning curve. Harv. Bus. Rev., Vol.42, No.1, Jan. 1964, pp.125-139.

9. Perkins, J.H. \& Enuendy, G. Use of the learning curve to forecast trends of chemical prices. American Association of Cost
Engineering, 10th Annual Meeting, Philadelphia, June 20-22, 1966.

10. Cole, R.R. Increasing utilization of the cost quantity relationship in manufacturing. J. Ind. Eng., May - June 1958, pp.173-177.

11. Andreas, F.J. The learning curve as a production tool. Harv. Bus. Rev., Vol. 52, No. 1, Jan-Feb 1954, pp.87-97.

12. The Boston Consulting Group. Perspectives on Experience. London: Boston Consulting Group, 1972.

13. Conley, P. Experience Curves as a Planning Tool. Boston: The Boston Consulting Group Inc., 1970.

14. Hedley, B. A Fundamental Approach to Strategy Development. Long Range Planning, December 1976, pp.2-11.

15. Henderson, B.D. The Experience Curve Reviewed. Boston: The Boston Consulting Group Inc., 1973.

16. Abell, D.F. \& Hammond, J.S. Strategic Market Planning. Englewood Cliffs: Prentice-Hall, 1979.

17. Johnston, J. Statistical Cost Analysis. New York: McGraw Hill, 1960, Ch. 4-5.

18. Conference on Price Research, Committee on Price Determination. Cost Behaviour and Price Policy. New York: National Bureau of Economic Research, 1943, Ch. 10.

19. Bain, J.S. Barriers to New Competition: Their Character and Consequences in Manufacturing Industries. Cambridge: Harvard University Press, 1956, pp.80-86.

20. Mansfield, E. Microeconomics: Theory and Applications.New York: Norton, 1975.

21. Perry, J.H. Chemical Engineer's Handbook. New York: McGraw Hill, 1963, pp.19.16- pp.19.99.

22. Mann, H.M. Seller concentration, barriers to entry and rates of return in thirty industries $1950-1960$. Rev. Econ. Stat., Vol. XLVIII, Aug. 1966, p.299.

23. Collins, N.R. \& Preston, L.E. Price cost margins and industry structure. Rev. Econ. Stat., Vol. LI, Aug. 1969, pp.271-286.

24. Shepherd, M. Texas Instruments: First Quarter and Stockholders' Meeting Report, 1973.

25. Sutermeister, R.A. People and Productivity. New York: McGraw Hill, 1969, pp.239-260.

26. Gregory, G. The March of the Japanese Micro. McKinsey $Q$., Spring 1980, pp.51-58.

27. Wheelwright, S.C. Japan where operations really are strategic. Harv. Bus. Rev., July-August 1981, p.67-74.

28. Buzell, R.D., Gale B.T. \& Sultan, R.G.M. Market share: A key to profitability. Harv. Bus. Rev., Vol. 53, Jan-Feb 1975, pp.97-106.

29. Kitching, J. Winning and losing with european acquisitions. Harv. Bus. Rev., March-April, 1974.

30. Schoeffler, S., Buzzell, R.D. \& Heany, D.F. Impacı of strategic planning on profit performance. Harv. Bus. Rev., Vol.52, No.2, March-April 1974, pp.137-145.

31. The Central Policy Review Staff. The Future of the British Car Industry. London: Her Majesty's Stationery Office, 1975.

32. Abell, D.F. Defining the Business. New Jersey: Prentice Hall, 1980.

33. Badler, G. Defining the Business. Notes: Strategic Planning Institute, Cambridge, Massachusetts, October 1981. 